\title{
APPLICATION OF VISUALIZATION, AUDITORY, KINESTETHIC (VAK) LEARNING MODEL FOR INCREASING UNDERSTANDING ENERGY CONCEPT
}

\section{Latifah Nur Khasanah, Hadi Mulyono, Retno Winarni}

Universitas Sebelas Maret

latifahnurkhas@gmail.com

\section{Article History}

accepted 09/07/2018

approved 01/08/2018

published 17/09/2018

\section{Keywords}

Learning Model

Visualization, Auditory,

Kinestethic (VAK), Energy

Concept

\begin{abstract}
The purpose of this research is to improve the understanding of energy concept by applying Visualization, Auditory, Kinestethic (VAK) learning model in third grade students of $S D$ Ta'mirul Islam Surakarta in academic year 2017/2018. The from of this research is Classroom Action Research (CAR) which the implementation is done with two cycles and each cycle there are two meetings. Eachcycle consists of four stages : planning, implementation, observation, and reflection. The subject of this research is the students of the third grade of SD Ta'mirul Islam Surakarta with the number of the students is 25 students. The techniques of collecting the data that used in this study are observation, interview, test, and documentation. The technique of validity test is the validity of content. The result of this research shows that there is an increase of value understanding the energy concept from preaction value until the implementation of cycle II.
\end{abstract}

Social, Humanities, and Education Studies (SHEs): Conference Series https://jurnal.uns.ac.id/shes

p-ISSN 2620-9284 e-ISSN 2620-9292 


\section{PENDAHULUAN}

Salah satu ilmu pengetahuan yang pembelajarannya dilakukan di jenjang sekolah dasar adalah IImu Pengetahuan Alam (IPA). IPA itu sendiri merupakan suatu cabang ilmu yang mempelajari tentang gejala atau fenomena alam yang ada disekitar lingkungan hidup manusia. James Conant (dalam Samatowa, 2016; 1), mendefinisikan bahwa sains sebagai suatu deretan konsep serta skema konseptual yang berhubungan satu sama lain, dan yang tumbuh sebagai hasil eksperimentasi dan obeservasi, serta berguna untuk diamati dan dieksperimentasikan lebih lanjut. IImu pengetahuan alam merupakan terjemahan kata-kata dalam bahasa inggris yaitu natural science, yang artinya ilmu penegtahuan alam (IPA). Berhubungan dengan alam atau bersangkut paut dengan alam, science artinya ilmu pengetahuan. Jadi, ilmu pengetahuan alam (IPA) atau science itu pengertiannya dapat disebut sebagai ilmu tentang alam. Ilmu yang mempelajari peristiwa-peristiwa yang terjadi di alam ini. Pendapat yang berbeda jugadisampikan oleh H.W. Fowler(dalam Trianto, 2010: 136), bahwa IPA adalah pengetahuan yang sistematis dan dirumuskan, yang berhubungan dengan gejala-gejala kebendaan dan didasarkan terutama atas pengamatan dan deduksi.

Proses pembelajaran IPA di sekolah dasar, juga terdapat beberapa masalah yang kemudian dapat menghambat proses pembelajaran yang berlangsung di dalam kelas. Masalah-masalah tersebut diantaranya seperti kurangnya minat, pemahaman dan motivasi belajar yang dimiliki oleh peserta didik. Karena selama ini proses pembelajaran IPA yang berlangsung selalu identik dengan pembelajaran yang pasti didominasi dengan kegiatan praktik atau demonstrasi dan kegiatan menghafal. Untuk siswa yang dalam penangkapan materi dengan cara menghafal memang sangat mudah untuk menangkap materi yang diajarkan oleh guru dan yang pasti hasil belajarnya akan menjadi lebih baik. Tetapi berbeda dengan peserta didik yang dalam penghafalannya kurang, akan merasa kesulitan, sehingga mengakibatkan hasil belajar peserta didik menjadi rendah. Kemudian dari masalah tersebut harus segera dipecahkan dan dicarikan solusinya.

Di SD Ta'mirul Islam Surakarta, tepatnya di kelas III ada beberapa aspek yang masuk kedalam materi IPA, diantaranya, (1) ciri-ciri dan kebutuhan makhluk hidup: (2) lingkungan: (3) benda dan sifatnya: (4) energi dan perubahannya: (5) menerapkan konsep energi gerak: (6) bumi dan alam semesta. Pada bab 4 yaitu energi dan perubahnnya terdapat pada semester II.

Haryanto (2012: 131), mengemukakan bahwa energi adalah kemampuan untuk melakukan usaha (kerja). Energi berasal dari bermacam-macam sumber. Jadi, dapat disimpulkan bahwa energi merupakan sesuatu yang berasal dari berbagai macam sumber energi yang dapat melakukan usaha. Energi itu sendiri ada beberapa bentuk atau macamnya, diantaranya, energi panas dan energi cahaya, energi gerak, energi getaran, energi listrik, dan energi kimia. Penggunaan energi seringkali dijumpai di kehidupan sehari-hari, mengingat kegunaan energi ini sangat penting bagi kehidupan sehari-hari. Namun, pemahaman konsep tentang energi ini masih sangat rendah untuk dikuasai oleh siswa terutama pada siswa kelas III di SD Ta'mirul Islam Surakarta. Rendahnya pemahaman siswa inilah yang membuat hasil belajar IPA siswa tentang energi menjadi rendah atau kurang.

Hal tersebut terlihat dari kegiatan obeservasi pada siswa kelas III $\mathrm{H}$ yaitu pada tanggal 18 Januari 2018, rendahnya pemahaman konsep tentang energi ini disebabkan oleh beberapa faktor, diantaranya, guru dalam cara mengajar masih dengan cara yang monoton atau masih bersifat teacher center serta guru belum menerapkan suatu model pembelajaran yang inovatif untuk meningkatkan keaktifan siswa dalam mengikuti proses pembelajarn di kelas, dan pada saat proses pembelajarn tersebut guru masih belum melaksanakan kegiatan praktikum datau 
praktik secara langsung dalam menjelaskan suatu materi, khususnya pada pembelajaran IPA.

Hasil dari kegiatan observasi tersebut kemudian dikuatkan dengan kegiatan wawancara yang dilakukan pada tanggal 20 Januari 2018 dengan guru kelas III H. Hasil dari wawancara tersebut yaitu, pada kegiatan belajar mengajar pada mata pelajaran IPA guru belum menerapkan suatu model yang sesuai dengan cara belajar siswa. Guru memberikan alasan kenapa tidak menerapkan model pada sat pembelajaran di kelas karena menurut beliau siswa sudah sangat nyaman dan siswa juga sudah mau memperhatikan dengan pelajaran yang dilaksanakannya setiap kali pembelajaran. Tetapi pemahaman siswa mengenai energi masih rendah. Kemudian pada saat melaksanakan kegiatan wawancara dengan siswa, informasi yang di dapat yaitu, menurut siswa proses pembelajaran IPA masih sangat kurang menarik, sehingga membuat siswa menjadi cepat bosan sehingga menyebabkan pemahaman siswa mengenai energi masih rendah.

Berdasarkan hasil wawancara tersebut, kemudian dikuatkan lagi dengan hasil pretest yang dilaksanakan pada 24 Januari 2018. Hasil pretest tersebut ternyata menunjukkan bahwa pemahaman konsep siswa mengenai materi energi masih banyak yang mendapatkan nilai di bawah KKM (Kriteria Ketuntasan Minimal) yaitu 75. Pada pelakasanaan pretest tersebut mengacu pada indikator pencapaian yang telah dibuat, yaitu meliputi menjelaskan maksud dari sumber energi dan energi, menyebutkan macam-macam bentuk energi, menyebutkan sumber-sumber energi yang terdapat di sekitar kita, menjelaskan tujuanpenggunaan sumber energi, serta menyebutkan contoh dari masing-masing energi yang ada disekitar kita. Dari hasil prestest tersebut, diperoleh nilai dari siswa bahwa pemahaman konsep siswa mengenai energi hanya beberapa siswa yang mendapatkan nilai diatas KKM (Kriteria Ketuntasan Minimal) dengan presentase ketuntasan hanya 12\% atau hanya 3 siswa dari 25 siswa. Sebanyak 22 siswa yang masih belum mendapatkan nilai sama dengan atau diatas KKM yaitu nilai diatas 75 dengan presentase $88 \%$. Berdasarkan hasil tersebut menunjukkan bahwa pemahaman konsep mengenai energi masih sangat rendah.

Berdasarkan hasil observasi, wawancara, dan pretestyang telah dilakukan tersebut menunjukkan adanya masalah tentang pamahaman konsep siswa. Masalah tersebut disebabkan karena guru pada saat mengajar di kelas masih dengan cara monoton atau teacher center dan masih belum menerapkan model pembelajaran yang inovatif. Kemudian dari masalah yang muncul tersebut, maka perlu dilakukan atau dicarikan upaya atau solusi untuk menciptakan proses kegiatan belajar mengajar IPA yang lebih inovatif dan kreatif. Upaya yang akan peneliti lakukan untuk mengatasi masalah tersebut yaitu dengan cara menerapakan suatu model pembelajaran yang aktif dan inovatif, salah satunya yaitu model pembelajaran Visualization, Auditory, Kinestethic (VAK). Menurut Huda (2015: 289), model pembelajaran Visualization, Auditory, Kinesetethic (VAK) adalah suatu gaya model belajar multi sensorik yang melibatkan tiga unsur gaya belajar, yaitu penglihatan, pendengaran, dan gerakan. Visual, modalitas visual mengakses citra visual yang diciptakan maupun diingat, seperti warna, hubungan ruang, potret mental, dan gambar.

Alasan peneliti memilih model VAK karena model ini menerapkan beberapa cara gaya belajar anak, yaitu melibatkan penglihatan, pendengaran, dan gerakan. Jadi menjadikan proses kegiatan belajar mengajar di kelas pada pembelajaran IPA khusunya materi energi menjadi lebih efektif, mengaktifkan siswa, dan nyaman bagi siswa. Model VAK ini juga mempunyai kelebihan, menurut Shoimin (2016: 228), kelebihan tersebut diantaranya, yaitu sebagai berikut : (1) pembelajaran akan lebih efektif karena mengombinasikan ketiga gaya belajar: (2) mampu melatih dan mengembangkan potensi siswa yang telah dimiliki oleh pribadi masing-masing: (3) memberi pengalaman langsung kepada siswa: (4) mampu melibatkan siswa secara maksimal dalam menemukan dan memahami suatu konsep melalui kegiatan fisik, 
seperti demosntrasi, percobaan, observasi, dan diskusi aktif: (5) mampu menjangkau setiap gaya pembelajaran siswa: (6) siswa yang memiliki kemampuan bagus tidak akan terhambat oleh siswa yang lemah dalam belajar karena model ini mampu melayani kebuutuhan siswa yang memiliki kemampuan di atas rata-rata.

\section{METODE}

Jenis penelitian ini adalah Penelitian Tindakan Kelas (PTK). Tujuan dari penelitian ini adalah untuk memperbaiki proses belajar mengajar di kelas sehingga kompetensi yang diharapkan dapat tercapai. Pene-litian ini dilaksanakan di kelas III H SDTa'mirul Islam Surakarta tahun ajaran 2017/2018 yang berjumlah 25 siswa. Terdiri dari 14 siswa laki-laki dan 11 siswa perempuan.

Data yang didapatkan bersumber dari data primer yang meliputi guru dan siswa kelas III H SDTa'mirul Islam Surakarta tahun ajaran 2017/2018. Data sekunder yang diperoleh berupa dokumen penelitian.

Teknik yang digunakan dalam pengum-pulan data yaitu observasi, wawancara, tes, dan dokumentasi. Data yang diperoleh meng-gunakan teknik analisis interaktif Miles dan Huberman (Sugiyono,2015: 337) yang meli-puti empat tahap yaitu: pengumpulan data, reduksi data, penyajian data, dan penarikan kesimpulan.

\section{HASIL DAN PEMBAHASAN}

Berdasarkan hasil kegiatan observasi terhadap kinerja guru dan aktivitas siswa sebelum dilakukan penelitian, dan hasil wawancara dengan guru kelas dan siswa kelas III H SD Ta'mirul Islam Surakarta, Maka dapat disimpulkan bahwa nilai pemahaman konsep energi siswa masih rendah dan kurang. Data hasil pemahaman konsep energi siswa pada pratindakan dapat dilihat pada tabel 1 berikut ini:

Tabel 1. Frekuensi Nilai Pra Tindakan

\begin{tabular}{|c|c|c|c|c|c|}
\hline No. & Interval & $\begin{array}{l}\text { Frekuensi } \\
\text { (fi) }\end{array}$ & $\begin{array}{l}\text { Nilai tengah } \\
\text { (xi) }\end{array}$ & fi.xi & $\begin{array}{c}\text { Presentase } \\
(\%)\end{array}$ \\
\hline 1. & $26-37$ & 4 & 31,5 & 126 & 16 \\
\hline 2. & $38-49$ & 6 & 43,4 & 261 & 40 \\
\hline 3. & $50-61$ & 6 & 55,5 & 333 & 64 \\
\hline 4. & $62-73$ & 6 & 67,5 & 405 & 88 \\
\hline 5. & $74-85$ & 0 & 79,5 & 0 & 88 \\
\hline 6. & $86-97$ & 23 & 91,5 & 274,5 & 100 \\
\hline & umlah & 25 & 369 & 1399,5 & \\
\hline \multicolumn{4}{|c|}{ Skor rata-rata } & \multicolumn{2}{|c|}{$\begin{array}{r}1399,5 \\
55,28\end{array}$} \\
\hline & \multicolumn{3}{|c|}{ Ketuntasan klasikal } & \multicolumn{2}{|c|}{$12,00 \%$} \\
\hline & \multicolumn{3}{|c|}{ Nilai tertinggi } & \multicolumn{2}{|c|}{96} \\
\hline & \multicolumn{3}{|c|}{ Nilai terendah } & \multicolumn{2}{|c|}{26} \\
\hline
\end{tabular}

Berdasarkan dari data Tabel 1, diatas, masih terdapat siswa yang belum mencapai KKM yang telah ditentukan, yaitu sebesar 75 . Dari siswa 25 siswa yang belum tuntas yaitu sebesar88\% atau sebanyak 22 siswa dan yang sudah tuntas diatas KKM sebesar12\% atau terdapat 3siswa yang telah mencapai KKM yang telah ditentukan. Nilai terendah pada uji pratindakan yaitu 26 sedangkan nilai tertinggi yaitu 96.Kemudian aktivitas siswa pada pra tindakan hanya mencapai rata-rata skor 1,6 dan masuk kedalam kategori kurang baik. Sedangkan hasil observasi kinerja guru pada pra tindakan mencapai nilai rata-rata 2 , dengan kategori baik.Nilai pemahaman konsep energi siswa padasiklus I mengalami peningkatan, namun belum signifikan, masih bterdapat banyak siswa yang belum tuntas. Distribusi frekuensi nilai pemahaman konsep energi siswa siklus Idapat dilihat pada Tabel 2. bawah ini: 
Tabel 2. Frekuensi Nilai Siklus I

\begin{tabular}{|c|l|c|c|c|c|}
\hline No. & Interval & $\begin{array}{c}\text { Frekuensi } \\
\text { (fi) }\end{array}$ & $\begin{array}{c}\text { Nilai tengah } \\
\text { (xi) }\end{array}$ & fi.xi & $\begin{array}{c}\text { Presentase } \\
(\%)\end{array}$ \\
\hline $\mathbf{1 .}$ & $37-43$ & 1 & 41 & 41 & 4,16 \\
\hline $\mathbf{2}$ & $44-50$ & 0 & 48 & 0 & 4,16 \\
\hline $\mathbf{3 .}$ & $51-58$ & 1 & 55 & 55 & 8,32 \\
\hline $\mathbf{4 .}$ & $59-65$ & 7 & 62 & 434 & 37,48 \\
\hline $\mathbf{5 .}$ & $66-72$ & 012 & 69 & 828 & 87,48 \\
\hline $\mathbf{6 .}$ & $73-80$ & 3 & 76,5 & 229,5 & 99,96 \\
\hline \multicolumn{3}{|c|}{ Jumlah } & $\mathbf{2 4}$ & $\mathbf{3 5 1 , 5}$ & $\mathbf{1 5 8 7 , 5}$ \\
\hline \multicolumn{3}{|c|}{ Skor rata-rata } \\
\hline \multicolumn{3}{|c|}{ Netuntasan klasikal tertinggi } \\
\hline \multicolumn{3}{|c|}{ Nilai terendah } \\
\hline
\end{tabular}

Tabel 2. Siklus I diatas dapat diketahui bahwa siswa yang mendapatkan nilai di atas KKMhanya terdapat 3 siswa dari 24 siswa yang hadir mengikuti pembelajaran atau sebesar $12,50 \%$, sedangkansiswa yang memperoleh nilai di bawah KKM masih banyak yaitu 21 dari 24 siswa yang hadir mengikuti pembelajaran atau sebesar $87,50 \%$.Pada siklus I ini, nilai terendah yaitu 38,5sedangkan nilai tertinggi adalah 80 .

Hasil observasi aktivitas siswa pada pertemuan I memperoleh rata-rata 1,81 sedangkan pada pertemuan II rata-rata aktivitas siswa mengalami peningkatan mencapai 1,97. Dari dua pertemuan diperoleh rata-rata 1,89 dan masuk kedalam kategori cukup baik. Sedangkan kinerja guru pada pertemuan Imencapai nilai1,93, kemudian pertemuan II meningkat menjadi 2,13. Sehingga rata-rata dari dua pertemuan tersebut yaitu 2,03 dan masuk kedalam kategori baik.

Berdasarkan rata-rata pada siklus I, indikator kinerja yang telah ditentukan pada siklus I belum tercapai yaitu $85 \%$ dan mengalami peningkatan dibandingkan dengan pratindakan, namun belum begitu banyak penigkatannya. Oleh karena itu, penelitian perlu perbaikan dan dilanjutkan ke siklus II.

Pada pelaksanaan siklus II, nilai pemahaman konsep energi pada siklus II menunjukkan adanya peningkatan. Hasil belajar siswa meningkat dan telah mencapai indikator kinerja yang telah ditentukan yaitu sebesar $85 \%$. Peneliti mengakhiri siklus dalam pembelajaran IPA materi energi. Berikut hasil nilai pemahaman konsep energi siswa pada siklus II dapat dilihat pada Tabel 3. dibawah ini:

Tabel 3. Frekuensi Nilai Siklus II

\begin{tabular}{|c|c|c|c|c|c|}
\hline No. & Interval & $\begin{array}{l}\text { Frekuensi } \\
\text { (fi) }\end{array}$ & $\begin{array}{l}\text { Nilai tengah } \\
\text { (xi) }\end{array}$ & fi.xi & $\begin{array}{c}\text { Presentase } \\
(\%)\end{array}$ \\
\hline 1. & $77-79$ & 2 & 78 & 156 & 9,09 \\
\hline 2. & $80-82$ & 5 & 81 & 405 & 31,81 \\
\hline 3. & $83-85$ & 8 & 84 & 672 & 68,17 \\
\hline 4. & $86-88$ & 2 & 87 & 174 & 77,26 \\
\hline 5. & $89-91$ & 2 & 90 & 180 & 86,35 \\
\hline 6. & $92-94$ & 3 & 93 & 279 & 99,98 \\
\hline & Jumlah & 22 & 513 & 1866 & \\
\hline \multicolumn{4}{|c|}{ Skor rata-rata } & \multicolumn{2}{|c|}{84,40} \\
\hline \multicolumn{4}{|c|}{ Ketuntasan klasikal } & \multicolumn{2}{|c|}{$95,45 \%$} \\
\hline \multicolumn{4}{|c|}{ Nilai tertinggi } & \multicolumn{2}{|c|}{93,5} \\
\hline \multicolumn{4}{|c|}{ Nilai terendah } & \multicolumn{2}{|c|}{77} \\
\hline
\end{tabular}

Setelah dilaksanakan penelitian di siklus II maka data yang diperoleh telah menunjukkan bahwa terdapat 21 siswa atau sebesar $95,45 \%$ yang mendapatkan nilai 
di atas KKM dan 1 siswa atau sebesar 4,54\% mendapat nilai di bawah Kriteria Ketuntasan Minimal (KKM). Pada siklus II, nilai terendah sebesar 77, sedangkan nilai tertinggi mencapai 93,5 dan rata-rata nilai pada siklus II mencapai 84,40.

Aktivitas siswa pada siklus II pertemuan I mencapai skor rata-rata 2,5. Sedangkan pada pertemuan II mencapai skor rata-rata 2,9. Jadi rata-rata pada pertemuan Idan II yaitu 2,7. Kemudian pada hasil observasi kinerja guru pada pertemuan I mencapai skor rata-rata 2,9, sedangkan pada pertemuan II mencapai skor rata-rata 3,2. Jadi rata-rata pada kedua pertemuan yaitu sebesar 3,05. Dari penelitian tindakan kelas yang telah dilaksanakan dalam dua siklus, dapat disimpulkan bahwa penerapan model Predict Observe Explain (POE) dapat meningkatkan pemahaman konsep gaya pada siswa kelas IV SD Negeri Munggung 1 Surakarta tahun ajaran 2017/2018. Di bawah ini gambar perbandingan nilai pemahaman konsep energi siswa :

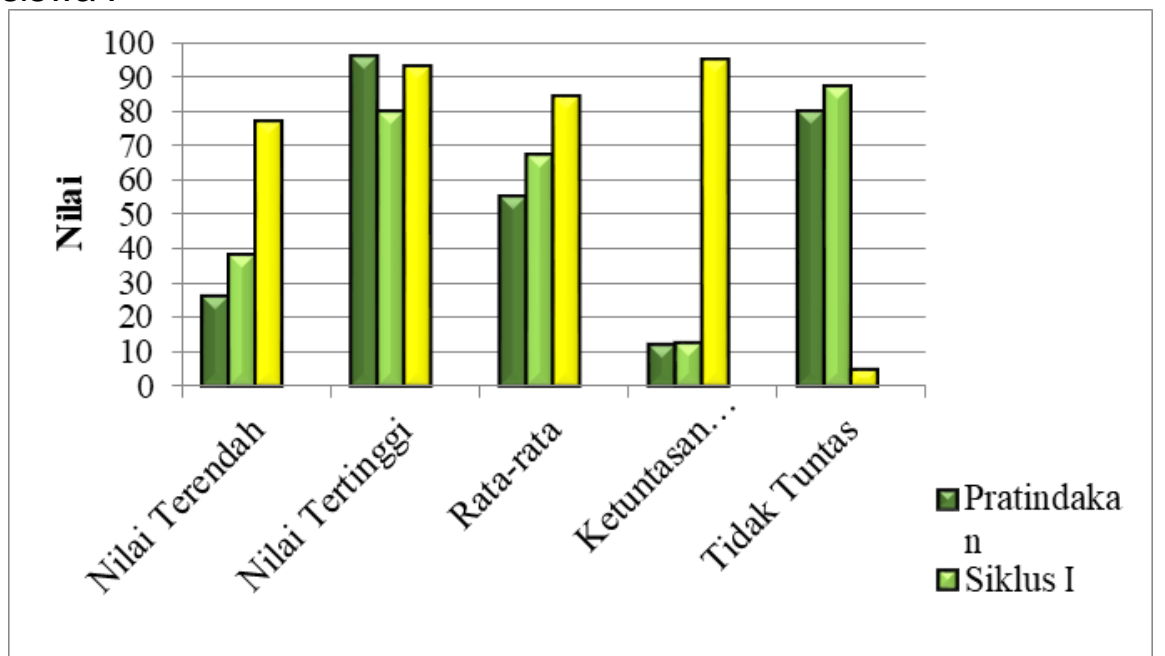

\section{Gambar 1. Perbandingan Nilai Pemahaman Konsep Energi Siswa Antar} Siklus

Berdasarkan deskripsi pratindakan dan hasil tindakan dapat diketahui bahwa pemahaman konsep energi siswa mengalami peningkatan pada setiap siklusnya hingga siklus II telah mencapai indikator kinerja yang telah ditentukan, yaitu sebesar $85 \%$. Hal tersebut menunjukkan bahwa model pembelajaran Visualization, Auditory, Kinestethic (VAK) yang telah diterapkandapat meningkatkan pemahaman konsep energi pada siswa kelas III H SD Ta'mirul Islam Surakarta tahun ajaran 2017/2018.

Setelah dilaksanakan tindakan pada siklus I, siklus II dan analisis data, maka dapat diketahui bahwa pemahaman konsep energi pada siswa kelas III H SD Ta'mirul Islam Surakarta mengalami peningkatan yang sangat signifikan. Meningkatnya pemahaman konsep energi siswa pada penelitian ini telah terlihat dari meningkatnya perolehan nilai rata-rata yang diperoleh dan telah mencapai Kriteria Ketuntasan Minimal (KKM). Pada saat pratindakan nilai rata-rata adalah 55,28 , kemudian pada siklus I meningkat, namun belum begitu terlihat, menjadi 67,47 sedangkan pada saat dilakukan siklus II kembali mengalami peningkatan lagi menjadi 84,40 . Sedangkan ketuntasan klasikal pemahaman konsep energi pada saat pratindakan terdapat 3 siswa atau sebesar $12 \%$ yang mendapat nilai $\geq \mathrm{KKM}$, yaitu sebesar 75 . Kemudian setelah dilaksanakan siklus I ketuntasan klasikal meningkat, namun belum begitu signifikan, yaitu hanya terdapat 3 siswa dari 24 siswa yang hadir mengikuti pembelajaran yang mencapai nilai 75 atau sebesar $12,50 \%$. Setelah dilakukan siklus II, ketuntasan klasikal kembali meningkat, yaitu terdapat 21 siswa dari 22 siswa yang hadir mengikuti pembelajaran atau sebesar 95,45\%.

Peningkatan pemahaman konsep energi pada siswa kelas III H SD Ta'mirul Islam Surakarta ini dikarenakan guru menerapkan model pembelajaran Viusalization, 
Auditory, Kinestethic (VAK)dan model tersebut telah memberikan dampak positif terhadap pemahaman konsep energi pada siswa kelas III H SD Ta'mirul Islam Surakarta. Hal tersebut diperkuat oleh pendapat Shoimin (2014: 228) mengemukakan beberapa kelebihan model pembelajaranVisualization, Auditory, Kinestethic (VAK) salah satunya yaitumemberikan pengalaman langsung kepada siswa, melibatkan siswa secara maksimal dalam menemukan dan memahami suatu konsep melalui kegiatan fisik, seperti percobaan, demonstrasi, dan diskusi aktif. Seperti pendapat Hamdani dalam jurnal internasional bahwa model VAK mengidentifikasi tiga tipe peserta didik berdasarkan bagaimana pelajar belajar lebih efektif, yaitu pembelajar visual adalah mereka yang belajar hal terbaik melalui penglihatan mereka, pembelajar auditori adalah mereka yang belajar hal terbaik dengan melalui pendengaran mereka, dan pembelajar kinestetik adalah mereka yang belajar hal terbaik saat berhubungan fisik dengan lingkungan, seperti bermain atau melakukan demonstrasi. Menurut Huda (2015; 289) mengungkapkan bahwa model pembelajaran Visual, Auditory, dan Kinestethic adalah suatu gaya model belajar multi sensorik yang melibatkan tiga unsur gaya belajar, yaitu penglihatan, pendengaran, dan gerakan. Visual, modalitas visual mengakses citra visual yang diciptakan maupun diingat, seperti warna, hubungan ruang, potret mental, dan gambar.

\section{SIMPULAN}

Berdasarkan hasil pelaksanaan Penelitian Tindakan Kelas (PTK) yang dilaksanakan dan pembahasan, maka dapat disimpulkan bahwa penerapan model pembelajaran Visualization, Auditory, Kinestethic (VAK)dapat meningkatkan pemahaman konsep energi pada siswa kelas III H SD Ta'mirul Islam Surakarta tahun ajaran 2017/2018. Pada siklus I nilai rata-rata meningkat menjadi 67,47 sedangkan pada siklus II kembali mengalami peningkatan menjadi 84,40. Ketuntasan klasikal pemahaman konsep energi juga mengalami peningkatan.

Pelaksanaan siklus I ketuntasan klasikal siswa meningkat, namun belum signifikan, yaitu sebesar $12,50 \% \%$ atau 3 siswa dari 24 siswa yang hadir mengikuti pembe;ajaran sedangkan pada siklus II kemba;i mengalami peningkatan menjadi $95,45 \%$ atau sebanyak 21 siswa dari 22 siswa yang hadir mrngikuti pembelajaran. Dengan indikator kinerjayang telah ditentukan yaitu sebesar $85 \%$, maka penelitian ini dinyatakan telah berhasil.

\section{DAFTAR PUSTAKA}

Hamdani. D. A. (2014). Exploring Students Learning Style At a Gulf University: A Contributing Factor to Effective Instruction:

Haryanto. (2012). Sains Untuk SD/MI Kelas III. Jakarta: Penerbit Erlangga.

Huda, M. (2015). Model-model Pengajaran dan Pembelajaran. Yogyakarta: Pustaka Pelajar.

Samatowa, U. (2010). Pembelajaran IPA di Sekolah Dasar. Jakarta: Permata Puri Media.

Shoimin, A. (2016). 68 Model Pembelajaran Inovatif dalam Kurikulum 2013. Yogyakarta: Ar-Ruzz Media.

Siswanto,W\& Ariani,D. (2016). Model Pembelajaran Menulis Cerita. Bandung: PT Refika Aditama. 